\title{
How Consumer Brand Engagement Effect on Purchase Intention? The Role of Social Media Elements
}

\author{
MUHAMMAD BILAL*, ZENG JIANQU and JUNLAN MING \\ School of economics and management, Beijing university of posts \\ and Telecommunications, Beijing, China.
}

\begin{abstract}
This paper examines the effect on consumer-purchase intentions of social media marketing components, including entertainment, engagement, eWOM, and trendiness. The study was conducted among Chinese consumers who have social media account and are aware of the effects of social media marketing on consumer purchase intentions. Datacollected data from 260 experienced social media users in Beijing and Shanghai. We used structural equation modeling (SEM) to evaluate the connections with SMM components, customer brand engagement, and purchasing intention. The findings demonstrate that interaction, entertainment, eWOM, and trendiness are core factors that specifically affect customer brand interest and purchasing intention. Social Media is a marketing medium in sharing brandintention. However, it remains to be seen how appropriate these components are for these purposes -related knowledge and its function to enhance customer brand engagement and purchasing. This research contributes to the development of a model that will aid practitioners and researchers in evaluating and explaining the impact of SMM on Consumer Purchase Intention in China.
\end{abstract}

\section{Introduction}

Consumer-brand engagement (CBE) is a marketing research zone that draws considerable attention. (Hollebeek et al., 2019; Harmeling et al., 2017 Keller et al., 2016). More than $80 \%$ of marketers in the next few years will aim to involve customers by developing a connectionwith them based on predictions that loyal consumers will join $40 \%$ more each year, adding a profitability premium of $20 \%$. Defined as "consumers' brand-related cognitive, emotional and behavioral activity connected to focal brand interactions" (Hollebeek et al., 2014, p. 149), CBE is a multi-disciplinary idea withemotive, rational, and behavioral scopes (Gomez et al., 2019; MartosPartal et al., 2015). Research attention derives from the awareness of the prominence of CBE to the

CONTACT Muhammad Bilal 1 bilal_ashraf30@hotmail.com $\mathbf{9}$ School of economics and management, Beijing university of posts and Telecommunications, Beijing, China.

\section{(c) (i)}

(C) 2021 The Author(s). Published by Enviro Research Publishers.

This is an Open Access article licensed under a Creative Commons license: Attribution 4.0 International (CC-BY).

Doi: http://dx.doi.org/10.12944/JBSFM.02.01.06 
marketing campaign, particularly the establishment and improvement of consumer-brand relationships (Bilal, et al., 2019; Butler, 2014).

Consumer engagement focuses on psychological states that consumers experience as a result of their interactions with the product, organization, and other consumers (Foroudi et al., 2014; Hollebeek et al., 2014). Consumer engagement has received high volume attention as a new idea in latest information systems and marketing studies. (Ma and Zhan, 2016; Dessart et al., 2015).According to research on the antecedents of consumer engagement in online brand communities' consumers interested to engage in online communities when they believe they will assistance from the brand, firms, or brand community. the degree of engagement differs Even though customers receive the same benefits from the brand or culture, (Brodie et al., 2013 Foroudi et al., 2014). As a result, current research lacks individuals' personal interactions in a given environment as well as their own characteristics, resulting in a context menu and simplistic explanation of customer engagement. Consumer engagement research that considers consumers' psychological experiences with SMM help us better understand the factors that stimulus consumer engagement in SMM and online purchasing intention.

In marketing research acknowledged as a primacy field (Foroudi et al., 2014; Abubakar et al., 2017), CBE is an essential framework for developing consumers' satisfaction and purchase intention (Coombs and Holladay, 2015) and for refining promotion usefulness (Yang et al., 2017), and business achievements (Webber, 2017). Accordingly, marketers are also trying to excavate their comprehension of how CBE is created, fostered, and preserved (Calderet al., 2016; Schultz and Peltier, 2013). Thus, there are also demands for firming up the theoretical structure sustaining CBE through empirical proof (Kim et al., 2012; Foroudi et al., 2014), particularly regarding what concerns its consequents and antecedents (Bento et al., 2018). There is a need for practical CBE study to strengthen the perception of constructs, drivers, and processes, such as the use of marketing discussion for the acquisition and preservation of customers by the improvement of customer-brand relationships.
It is estimated that 74 percent of online users use social media sites (Islam and Rahman, 2016), and more than fifty percent of social media channels receive brand-related facts from the following brand accounts (Ismail, 2017). Statista, (2019b) Latest scientific estimates measure the global rate of social media penetration at 42 percent, monthly with over three billion vigorous users. This usage explains why over ninety percent of companies currently contain social media contact in their marketing campaigns by YouTube, Instagram, Facebook, and Twitter, to share product-related information to the customer (Trump, 2014). Companies use social media channel to discuss information about products, such as generating feedback and spreading new feature, as well as to gain information about customer choice and to a stable relationship with consumers, all that makes it easy to create CBE and promote Purchase intention (Harrigan et al., 2017; Grappi and Romani, 2015).

Marketers apprehend the superiority of SMM in terms of contact with consumers and brand-building practices over traditional advertising (Hollebeek et al., 2014;Park and Reber, 2011). Accordingly, Shao (2009) the subject of current research to age is generally on the attraction of user-sharing content, on creative strategies, and content analysis (Ashley and Tuten, 2015; Shen and Bissell, 2013), and consumers' behavior as a sharebrand community on social-media (Kim et al.,2019). As a result, SMM is entirely perceived to be a fairly recent marketing method, and the understanding of how it affects CBE remains narrow (Grappi and Romani, 2015; Rohm et al., 2013).

This paper explores the impression of SMM elements, namely interaction, customization, ande WOM, trendiness, and customization, on $\mathrm{CBE}$ and purchase intention. We continue to study the related literature to find research gaps critically. This expedites the design of a theoretical framework in which SMM elements serve as CBE drivers and purchase intention. Next, explain the methodology and realistic analysis results, monitored by implications, limitations, and future directions. 


\section{Hypotheses and Model Development}

A perilous analysis of the literature dealing with SMM, purchase intention, and CBE underlies the consequent expansion of the theoretical structure and is used to direct scientific studies into SMM elements' effect on CBE and purchase intention.

\section{Social-Media Marketing (SMM)}

Social Media denotes to "a group of Internet-based presentations that shapes on the technological and ideological basics of Web 2.0 and that permits the exchange and formation of user-generated content" (MSI, 2018). It is regarded as most one relevant engagement channels for product variety information due its immersive features provide for involvement, collaboration, and information sharing practices (Pansari and Kumar 2017), with a high volume for contact the community instead of old media, such as radio, TV, and print (Bowen, 2015). Zeng and Gerritsen (2014), explained social media include content community sites, consumer reviews, internet facilities, and social networking sites (Tess, 2013). Arguably, increasing business community to discuss about the brand via SMM platform, as well as advertising on social site, managing consumersharing content, all with the goal of developing reliable and favorable brand information in the mind of the consumer (Ashley and Tuten, 2015).

\section{Entertainment}

The former discussion on SMM elements and brand contact with engaging elements is viewed as enjoyable and playful (Cunningham et al., 2019). In reality, engaging SMM content can offer customers enjoyable and fascinating details to deepen their affinity for a brand (Lin and Kloet, 2019; Curras-Perez et al., 2014). For instance, the study suggests that brand pages with games, narratives, competitions, presents, interactive animations, photographs, and videos are viewed as enjoyable, entertaining, and flashy, generating enthusiasm and meeting the consumer's aesthetic pleasure and emotive needs, such that customers are motivated to purchase brand-related content (Plantin et al. 2018). Brand Page Entertainment Appeal transforms into favorable customer experiences, thereby creating consumer spiritual engagement in the brand (Nieborg and Poell, 2018; Ashley and Tuten, 2015;). Thus:

\section{H1. Entertainment Is Associated with Consumer- Brand Engagement}

\section{'Interactivity}

Interactive brand pages on social media promote contact between customer and brands and affect the generation of favorable impressions of a brand (Lin and Kloet, 2019). Sharing a link to the official website of the brand, as well as promoting the sharing and dissemination of knowledge relating to the brand among consumers, can increase interactivity (Mishra, 2019). Marketers can also promote users' involvement through the submission of their statement, sharing feedback, and subscribing to the company website (Zhu and Chen, 2015), These customer engagement practices are essential in enhancing experiences between brands and consumers (Merrilees, 2016). The result enhances customers' semantic awareness of product characteristics and brand benefits (France et al., 2016). In the Chinese social media, such as We Chat, RenRen, and Weibo, often encourage consumers to share ideas with compatible others about particular products and reinforce the mutual concernbetween shoppers and companies (Lin and Kloet, 2019; Bowen, 2015). Such experiences can eventually lead to a higher degree of excitement and corresponding production of liking (Godey et al., 2016), by facilitating customers to give their feedback to companies, thereby allowing firms to increase the worth of their products and services (Merrilees, 2016).

\section{H2. Interactivity is Associated with Consumer- Brand Engagement.}

\section{eWOM}

Social media development has expanded the digit of customers who calculate products and brands based on eWOM (Goh et al., 2013; Lien and Cao 2017; Bilal, et al. 2020). This is expected to positively impact their appraisal of goods and services, pushing users to spend further perceptive energy readinge WOM (Xu et al. 2018). Considering the reliability of social media sites presumed stability of social media sites (Cheung et al., 2011), The creation and exchanging of eWOM among customers creates a logic of cohesion and the emotive association between products and consumers (Malthouse2013), 
sharing positive attachment among customers (Liang et al. 2019). Thus, the availability and use of eWOM on social media channels tend to shape favorable brand impressions and positive feelings for the exact brand, thus improving the consumerbrand partnership.

\section{H3. eWOM is Associated with CBE.}

Consumers feel inspired to consume up-to-date content on products on social media sites in order to stay up-to-date with the new updates on brands and awareness of related trends (Chen and Qiu (2019). Brand trendiness can add to the observation of the brand as a top product encouraging consumers to check for the hottest information on social networks, thereby donating to creating a positive brand understanding in the thoughts of consumers. In specific, trendy conversation subjects and the newest product news accessible on the brand's Social media page successfully promote customer ingenuity to address them with friends, thereby improving consumer cognitive existence in brandrelated experiences and helping to build favorable brand impressions (Chan et al., 2014). As a result, the more stylish the details presented by the social media brand websites, the more successful it can be to engage customers (Malthouse2018). As such, trendiness information supports, catches consumers'consideration, arousingoptimisticmoods, and pouringfidelity intention (France et al., 2016). The claim byHollebeek's (2011) that improving customer rational and emotional existence leads to increasing CBE. Thus

\section{H4. Trendiness is Associated with Consumer- Brand Engagement.}

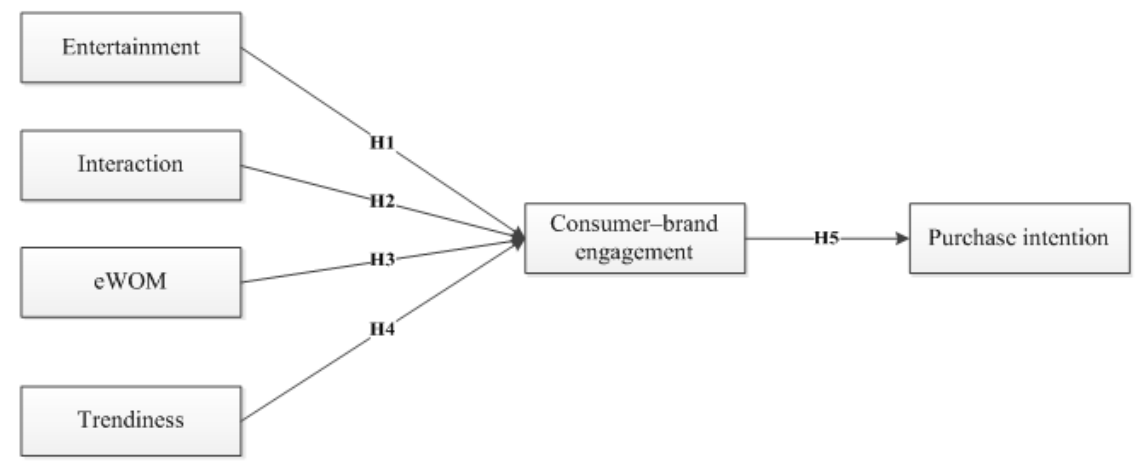

Fig. 1: Conceptual framework 1

Influence of Consumer-Brand Engagement on Purchase Intention

As per Martos-Partal et al.,(2015), in order to accomplish marketing targets, the interaction between consumers and the brand contributes a crucial part of the company's growth capacity. The probability of a customer purchasing intention for services and goods would be better if their purchasing experience is positive. Boyer and Hult (2006) conducted research on consumer behavioral intentions for online purchases using the data gathered from the survey, and their results revealed that, depending on the extent of customer service, they could adjust the buying intention. Customers who purchase the associated goods and services of the company would be persuaded by this method. More precisely, Magneto's report in
2015 showed that a 23 percent rise in revenue is a boost to Customer Loyalty because they pay more and more on each order. So, Yang and He (2011) concluded that customer spending choices would be affected by user interaction. This will result in a high purchase value for buyers, and a potential buyer's expense will decline. Theoretically, increasingly active shoppers are establishing a fairly popular pattern by persuading their loved ones like family members and mutual friends as consumers.

\section{H5: Consumer Engagement Influence Positively Consumer's Purchase Intention}

\section{Procedures and Methods}

This research was performed to achieve a deeper understandingof the social media elements 
entertainment, interaction, eWOM, trendiness, consumers brand engagement and purchase intention. An online survey was designed to determine customers' reactions to online vendor fairness in the recent previous. The condition of respondents to the survey was confirmed by the use of 3 separate requirements. First, consumers of We Chat necessity have an online purchase skill. Next, the respondents received a minimumof a single message in the moments of We Chat contacts through the recent month. Third, two main Chinese cities, Beijing and Shanghai, were decided for enhanced structure and convenience.

\section{Questioners Designing}

Although the target audience was in China, the steps introduced were initially in English, interpreted into Chinese, and translated back into English. We selected three postgraduate and two Chinese doctoral students who are in English major literature. In comparison, the Construction of this report has been updated numerous times with the aid of two language specialists in both Chinese and English to eliminate suspicions. Prior to administering the final review, a pilot sample of 50 respondents was performed to assess the effects. The findings of the pilot survey confirmed that the measurement items were fine interpreted and discussed.

The final survey was carried out to gather the requested data through online media. Online Media offers a convenient way to the public without any regional constraints and can also reduce the period and expense of the survey. The final edition of the survey method was drawn up on www.wjx.cn after iterative revisions. The link to the online survey form contains a cover letter for the user. The cover letter outlines the aims of this report, the Chinese social media (such as We Chat), the financial incentive, and a description of how the questions should be answered. Until responding to the survey,form participants were requested to recall the latest online shopping trip with items or services. The directions assumed were prepared transparent and simple for respondents to grasp the study goals.

Anover-all of 297 replies were obtained from respondentsduring September to November 2020. We dropped 37 responses, with inexperiencedshoppers and respondents who took fewer time to respond to the survey form. The final data of 260 respondents were deemed accurate in this research environment after the invalid responses were overlooked.

\section{Measurement}

All items of constructs were taken from the prior studies and modified according to this research setting. To measure the entertainment (four-items), interaction (four-items), trendiness (three-items), eWOM (three-items) all taken from Kim and Ko (2010).Consumer-brand engagement was measured with (four-items) modified Hollebeek et al., (2014). The purchase intentions (five items) were adapted from Jalilvand and Samiei (2012). A total of 23 items were evaluated on the five Likert scales ranging from "strongly disagree $=1$ " to "strongly agree $=5 "$. Table 1 shows the descriptive statistics of the sample.

\section{Results \\ Reliability and Validity}

Regarding the potential interactions between the diverse variables and their impacts on the eWOM client in the We Chat context, the validity of the measurements was validated using SEM, which is tested in 2 phases: confirmatory factor analysis (CFA) hypotheses analysis. First, AMOS 22.0 was used to assess CFA to approximate the factor's configuration and the model fit of the latent variables. Next, the structural model was analyzed to assess the hypothesized relationship between the variables.

In the CFA, objects were held if they were loaded over 0.50 on each factor (Arnold and Reynolds, 2003) and below this 0.30 on other factors (Klein, 1998). The calculation algorithm showed a strong fit model (chi-square $=342.51, \mathrm{df}=2.37, \mathrm{CFI}=0.92$, RMSEA $=0.05$, RMR $=0.05$, GFI $=0.93$, AGFI $=0.88, \mathrm{NFI}=0.96)$. Constructions demonstrated durability of (a) alpha coefficient estimates varying from 0.76-0.93, well above the 0.70 threshold values. (Hair, Black, Babin, Anderson, and Tatham, 1998), (b) composite reliability (CR) estimates exceeding the recommended 0.70 thresholds for all constructs and (c) average variance extracted (AVE) exceeding the recommended 0.50 threshold (Fornell and Lacker, 1981; Hair et al., 1998; Nunnally, 1978). See Table 2. 
BILAL et al., Journal of Business Strategy, Finance and Management, Vol. 02(1 \& 2) 44-55 (2021) 49

Table 1: Demographics of research sample $(N=260)$

\begin{tabular}{cccc}
\hline Characteristics & Category & Frequency & $\%$ \\
\hline \multirow{2}{*}{ Gender } & Male & 145 & 55.77 \\
& Female & 115 & 44.23 \\
& $18-25$ & 97 & 37.31 \\
& $26-30$ & 79 & 30.38 \\
Education Level & $31-40$ & 51 & 19.62 \\
& Over 40 & 33 & 12.69 \\
& Intermediate/High School & 39 & 15.00 \\
Frequency of using WeChat & Bachelors & 83 & 31.92 \\
& Masters & 64 & 24.62 \\
& Doctoral/PhD & 41 & 15.77 \\
Online Shopping Experience through WeChat. & Others & 33 & 12.69 \\
& Many times a day & 133 & 51.15 \\
& Several times a day & 93 & 35.77 \\
& Once a day & 34 & 13.08 \\
& $>1$ Years & 41 & 15.77 \\
& $1-2$ Years & 103 & 39.62 \\
& $3-4$ Years & 71 & 27.31 \\
& $<4$ Years & 45 & 17.30 \\
\hline
\end{tabular}

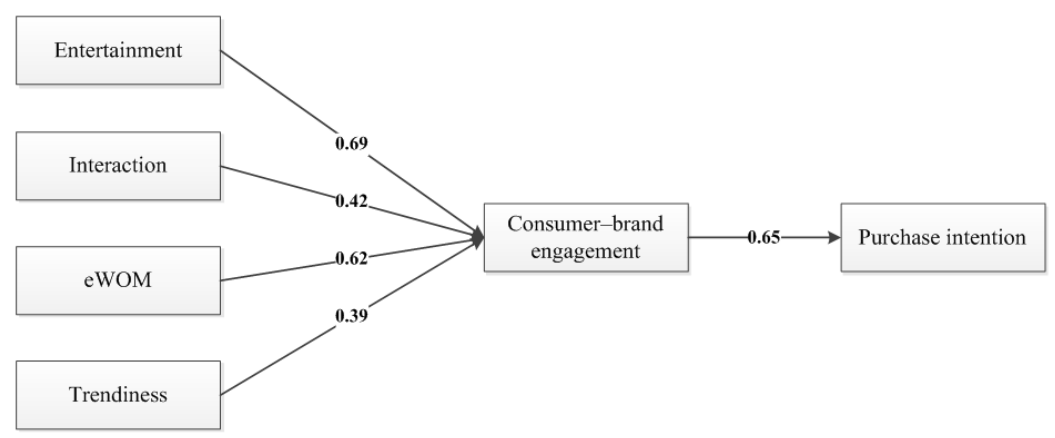

Fig. 2: Conceptual framework 2

Table 2: Reliability and Convergent Validity.72

\begin{tabular}{lccccccc}
\hline Variables & Items & Means & SD & Item Loading & CR & AVE & Cronbach's \\
\hline Entertainment & 4 & 3.203 & 0.632 & $0.76-0.93$ & 0.786 & 0.672 & 0.923 \\
Interaction & 4 & 4.152 & 0.434 & $0.81-0.91$ & 0.890 & 0.669 & 0.789 \\
Trendiness & 3 & 3.104 & 0.675 & $0.83-0.92$ & 0.787 & 0.672 & 0.842 \\
eWOM & 3 & 3.201 & 0.775 & $0.79-0.89$ & 0.890 & 0.602 & 0.769 \\
Consumer-brand engagement & 4 & 4.323 & 0.878 & $0.86-0.91$ & 0.932 & 0.647 & 0.885 \\
Purchase intentions & 5 & 3.232 & 0.897 & $0.80-0.93$ & 0.893 & 0.657 & 0.902 \\
\hline
\end{tabular}

Highest probability factor loadings implied converging validity of the underlying structures, which were strong and important (Wixom and Watson, 2001).
Such that, all factor loadings surpassed 0.5 and were very significant $(p<.001)$. Discriminant validity means that each latent variable is a different construct 
(Scott and Robert, 1998). This was calculated by matching the loading of the object correlated with its cross-loading factor on other factors. Each load on the factor was bigger than their cross-loading on unintentional variables (Henseler and Chin, 2010).
Discriminant validity was also supported by the fact that the similarities between the variables were minor than the corresponding square root of the AVE, as seen on the diagonal values in Table 3. (Fornell and Larcker, 1981).

Table 3: Discriminant Validity

\begin{tabular}{lccccccccc}
\hline Constructs & ENT & IN & TS & eWOM & CBE & PI & $\begin{array}{c}\text { Eigen } \\
\text { values }\end{array}$ & $\begin{array}{c}\% \text { of } \\
\text { Variance }\end{array}$ & $\begin{array}{l}\text { Cumulative } \\
\%\end{array}$ \\
\hline ENT & 0.749 & & & & & & 2.42 & 28.61 & 28.61 \\
IN & $0.231^{* * *}$ & 0.871 & & & & & 2.62 & 20.49 & 49.1 \\
TS & $0.312^{* *}$ & $0.501^{* * *}$ & 0.744 & & & & 2.43 & 18.31 & 67.41 \\
eWOM & $0.349^{* *}$ & $0.546^{* * *}$ & $0.434^{* *}$ & 0.809 & & & 2.32 & 14.27 & 81.68 \\
CBE & $0.331^{* *}$ & $0.423^{* *}$ & $0.433^{* * *}$ & $0.499^{* * *}$ & 0.812 & 2.44 & 13.38 & 95.06 \\
PI & $0.272^{* * *}$ & $0.532^{* * *}$ & $0.341^{* *}$ & $0.442^{* *}$ & $0.321^{* *}$ & 0.827 & 2.66 & 4.94 & 100 \\
\hline
\end{tabular}

Forentertainment, interaction, trendiness, eWOM were established to have a significant influence on consumer-brand engagement; the values of coefficient were $0.69,0.42,0.39$, and 0.63 ,oneto-one with a significant $p$-value which specifies that entertainment, interaction, trendiness, eWOM.
Hereafter, H1-4 was accepted. For H5,consumerbrand engagement wasoriginating to have a substantial impact on purchase intention. According to their significant $\mathrm{p}$-value, H5 was acceptedwith the significant coefficient and p-value0.65. Table 4.

Table 4: Model Structural SEM

\begin{tabular}{ccccc}
\hline $\mathbf{H}$ & Path & Estimates & SE & CR \\
\hline H1 & Entertainment $\rightarrow$ Consumer-brand engagement & 0.69 & 0.189 & $1.345^{\star *}$ \\
H2 & Interaction $\rightarrow$ Consumer-brand engagement & 0.42 & 0.169 & $2.239^{* * *}$ \\
H3 & Trendiness $\rightarrow$ Consumer-brand engagement & 0.39 & 0.187 & $2.311^{* * *}$ \\
H4 & eWOM $\rightarrow$ Consumer-brand engagement & 0.62 & 0.189 & $1.897^{* *}$ \\
H5 & Consumer-brand engagement $\rightarrow$ Purchase intentions & 0.65 & 0.191 & $2.575^{* * *}$ \\
\hline
\end{tabular}

$\mathrm{SE}=$ Standard Error; CR $=$ Critical Ratio. ${ }^{* * *} \mathrm{p}$-value $<0.001,{ }^{* *} \mathrm{p}<0.05$

\section{Discussion}

In the sense of a high-volume focal commodity, social media, the results specify that the effect of feedback on CBE and purchasing intention is the greatest, accompanied by eWOM and trendiness. As a consequence, engagement, EWOM, and trendiness attract close consideration when preparing SMM events. The study also showed that $\mathrm{CBE}$ had a clear and substantial influence on purchase intention. This finding means that CBE can not only be used as a means of improving brand recognition and awareness but also as an imperative element in creating brand value. Precisely, the results indicate that the impact of CBE on purchase intention is high and important, supporting the value of $\mathrm{CBE}$ in the brand-building framework. As a result, the discriminatory use of SMM elements will improve customer cognitive awareness, warmth and activation by helping to create deep and positive brand information in consumers' minds.

\section{Theatrical Implication}

The available literature suggests that SMM elements perform a significant position in the creation of CBE and purchasing intentions. This study reveals that commitment, eWOM, and trendiness are critical 
drivers for solidification CBE, promoting brand value and brand recognition, and fairly reflecting previous literature results. (Helmond, 2015; Plantin et al., 2018).eWOM, trendiness, and interaction can therefore be viewed as a way of growing consumer perceptive processing, kindliness, and activation for the crucial brand (Malthouse2018) and considered successful in shaping consumer brand attitudes.

The results also indicate that $\mathrm{CBE}$ has a clear and optimistic effect on the buying intention, reinforcing the value of CBE inbrand awarenessbuilding (France et al., 2016). In addition, the results specify the indirect impact on purchasing intention of contact, eWOM, and pattern. This more reflects the use of social media activity with digital media elements eWOM and trend-setting features in the process of brand-developing.

\section{Managerial Implication}

From a professional point of opinion, this study noises on advertisers to ruminate the use of SMM in order to improve their Purchasing intention. Rather than seeing SMM as merely another advertisement medium to meet customers, SMM is a significant method to help create CBE and buying intention (Foroudi et al., 2014; MSI, 2018).

The findings indicate that trendiness, interaction, and eWOM are important SMM elements for building CBE and purchasing intention for high-volume goods. Marketers should also advantage from integrating new and up-to-date digital content and promoting constructive eWOM. This is supposed to excite the consumer's cognitive processing, love, and stimulation (Hollebeek et al., 2016), essentially improving customer product information. The suggestion is, therefore, that advertisers should encourage (and, if possible, assist) consumers to get to what they are looking for, such as the EWOM specifics of specific goods (MSI, 2018), thereby enabling customers to spread eWOM on a voluntary basis.

It is also advised that marketer to manipulate the emotional reaction of consumers to a brand by successfully controlling their social media practices (Trump, 2014), possiblygratifyingconsumers who share their eWOM regularly with complete, valueadded, and understanding information on different social media channels (Wang et al., 2012).
Policymakers should cogitate a number of social media channels from which users can communicate their views with each other.

Marketers must also explore designing SMM programs that exploit the immersive functionality of SNSs. Marketers can achieve this by putting their social media brand forum that delivers guidance to address customer challenges by using their branded goods and inviting consumers to a social media-based consumer brand network where people can build a wisdom of connectivity within the brand community. Upgraded interactivity socialmedia brand space may result from the introduction of competitions in order to convince customers to abandon their designs for improving standing products or for fresh product innovations to play in return for gifts. Contests have proved successful in promoting customer engagement, thereby adding to the positive knowledge of consumer products (Chan and Guillet, 2011).

\section{Limitations and Future Research}

The results of this analysis must be viewed in the bright of such limitations. Respondents were requested to remember the latest online shopping experience before answering to thereesearch survey. They were interpreted within the context of transaction-specific expertise. This was not adequate for a stated amount of time. Conversely, customers can deliver eWOM on the basis of gradual decisions that have evolved over time, while they have experienced with the seller. Future studies might discuss how these distinctions account for eWOM generation users. The only online customers interested in exchanging eWOM via WeChat in two Chinese cities were surveyednamely (Beijing and Shanghai). Results cannot, however, be applied to other cities. Future studies may suggest the generalization of findings in other Chinese cities. The convenience sampling approach was used during the collection of data.Results may be made simpler and clarified by using other types of sampling, e.g., quotas and random sampling. The non-probability sampling technique can not characterize general Chinese online customers.

Finally, this study attentiveto the usefulness of SMM but did not explore any influence of old-style marketing elements, moreover in conjunction with SMM or differently. Future studies may relate 
BILAL et al., Journal of Business Strategy, Finance and Management, Vol. 02(1 \& 2) 44-55 (2021) 52

the comparative influence of SMM elements and traditional marketing elements, such as traditional ads and network latency, in order to identify which marketing variables are used. A moreconvincing effect on CBE and its purchase intention.

\section{Conclusion}

SM has experienced vigorous growth since it has become a common feature of everyday life. SMM is the best content source that can impact search activity, reading web feedback or ratings, making it a common approach for online users to pursue information before making the correct decision. The present study explored the SMM elements invarious directions, such as entertainment, eWOM, trendiness, and interactivity for online users in China. The findings suggest that these elements have a critical effect on CBE and buying intention. This research also explored the fact that comprehensiveness and validity of knowledge are the most problematic factors that can affect online consumer's purchasing behavior. Companies should manage the best plans to enhance the accessibility of online communities, include all relevant business details, and allow consumers to post their views in order to retain users and $\mathrm{CBE}$.

\section{Acknowledgment}

This work was supported by the research on big data in application for education of BUPT(2018Y0403), and the research project of cyberspace school at BUPT.

\section{Funding}

The author(s) received no financial support for the research, authorship, and/or publication of this article.

\section{Conflict of interest}

The authors declare there is no conflict of interest.

\section{References}

1. Abubakar, A. M., Ilkan, M., Al-Tal, R. M., \&Eluwole, K. K. (2017).eWOM, revisit intention, destination trust and gender. Journal of Hospitality and Tourism Management, 31, 220-227.

2. Arnold, M. J., \& Reynolds, K. E. (2003).Hedonic shopping motivations. Journal of retailing, 79(2), 77-95.

3. Ashley, C. and Tuten, T. (2015), "Creative strategies in social media marketing: an exploratory study of branded social content and consumer engagement", Psychology and Marketing, Vol. 32 No. 1, pp. 15-27.

4. Bento, M., Martinez, L.M. and Martinez, L.F. (2018), "Brand engagement and search for brands on social media: comparing generations $X$ and $Y$ in portugal", Journal of Retailing and Consumer Services, Vol. 43, pp. 234-241.

5. Bilal, M., Jianqiu, Z., Akram, U., Tanveer, Y., Sardar, T., \&Rasool, H. (2020). Understanding the Effects of Internet Usage Behavior on eWOM. International Journal of Information Systems in the Service Sector (IJISSS), 12(3), 93-113.

6. Bilal, M., Jianqiu, Z., Akram, U., Tanveer, Y., Sohaib, M., \&Raza, M. A. A. (2020). The Role of Motivational Factors for Determining Attitude
Towards eWOM in Social Media Context. International Journal of Enterprise Information Systems (IJEIS), 16(2), 73-91.

7. Bowen, J. (2015), "Trends affecting social media: implications for practitioners and researchers", Worldwide Hospitality and Tourism Themes, Vol. 7 No. 3, pp. 221-228.

8. Boyer, K.K. and Hult, G.T.M., 2006. Customer behavioral intentions for online purchases: An examination of fulfillment method and customer experience level. Journal of Operations Management, 24(2), pp.124-147.

9. Calder, B.J., Malthouse, E.C. and Maslowska, E. (2016), "Brand marketing, big data and social innovation as future research directions for engagement", Journal of Marketing Management, Vol. 32 Nos 5-6, pp. 579-585.

10. Chan, N.L. and Guillet, B.D. (2011), "Investigation of social media marketing: how does the hotel industry in Hong Kong perform in marketing on social media websites?", Journal of Travel and Tourism Marketing, Vol. 28 No. 4, pp. 345-368.

11. Chan, T.K., Zheng, X., Cheung, C.M., Lee, M.K. and Lee, Z.W. (2014), "Antecedents and consequences of customer engagement in online brand communities", Journal of Marketing Analytics, Vol. 2 No. 2, pp. 81-97. 
BILAL et al., Journal of Business Strategy, Finance and Management, Vol. 02(1 \& 2) 44-55 (2021) 53

12. Chen J and Qiu J (2019) Digital utility: datafication, regulation, labor, and DiDi'splatformization of urban transport in China. Chinese Journal of Communication 12: 274-289.

13. Cheung, C., Chiu, P.Y. and Lee, M. (2011), "Online social networks: why students use Facebook?", Computers in Human Behavior, Vol. 27 No. 4, pp. 1337-1343.

14. Coombs, W.T. and Holladay, S.J. (2015), "Public relations relationship identity in research: enlightenment or illusion", Public Relations Review, Vol. 41, No. 5, pp. 689-695.

15. Cunningham S, Craig D and Lv J (2019) China's livestreaming industry: platforms, politics, and precarity. International Journal of Cultural Studies 22: 719-736.

16. Curras-Perez, R., Ruiz-Mafe, C., Sanz-Blas, S., 2014.Determinants of user behavior and recommendation in social networks. Ind. Manage. Data Syst. 114 (9), 1477-1498.

17. Dessart, L., Veloutsou, C. and MorganThomas, A. (2015), "Consumer engagement in online brand communities: a social media perspective", The Journal of Product and Brand Management,

18. Fornell, C., \&Larcker, D. F. (1981).Evaluating structural equation models with unobservable variables and measurement error. JMR, Journal of Marketing Research, 18(1), 39-50. doi:10.1177/002224378101800104.

19. Foroudi, P., Melewar, T. C., \& Gupta, S. (2014). Linking corporate logo, corporate image, and reputation: An examination of consumer perceptions in the financial setting. Journal of Business Research, 67(11), 2269-2281.

20. France, C., Merrilees, B. and Miller, D. (2016), "An integrated model of customer-brand engagement: drivers and consequences", Journal of Brand Management, Vol. 23 No. 2, pp. 119-136.

21. Godey, B., Manthiou, A., Pederzoli, D., Rokka, J., Aiello, G., Donvito, R. and Singh, R. (2016), "Social media marketing efforts of luxury brands: influence on brand equity and consumer behavior", Journal of Business Research, Vol. 69 No. 12, pp. 5833-5841.

22. Goh, K.Y., Heng, C.S. and Lin, Z. (2013), "Social media brand community and consumer behaviour: quantifying the relative impact of user-and marketer-generated content", Information Systems Research, Vol. 24 No. 1, pp. 88-107.

23. Gomez, M., Lopez, C. and Molina, A. (2019), "An integrated model of social media brand engagement", Computers in Human Behavior, Vol. 96 July, pp. 196-206.

24. Grappi, S. and Romani, S. (2015), "Company post-crisis communication strategies and the psychological mechanism underlying consumer reactions", Journal of Public Relations Research, Vol. 27, pp. 22-45.

25. Hair, J. F., Black, W. C., Babin, B. J., Anderson, R. E., \&Tatham, R. L. (1998). Multivariate data analysis.

26. Harmeling, C., Moffett, J., Arnold, M. and Carlson, B. (2017), "Toward a theory of customer engagement marketing", Journal of the Academy of Marketing Science, Vol. 45 No. 3, pp. 312-335.

27. Harrigan, P., Evers, U., Miles, M. and Daly, T. (2017), "Customer engagement with tourism social media brands", Tourism Management, Vol. 59, pp. 597-609.

28. Helmond A (2015) The platformization of the web: making web data platform ready. Social Media + Society 1(2): 1-11.

29. Henseler, J., \& Chin, W. W. (2010). A comparison of approaches for the analysis of interaction effects between latent variables using partial least squares path modeling. Structural Equation Modeling, 17(1), 82-109. doi:10.1080/10705510903439003.

30. Hollebeek, L. (2011), "Demystifying customer brand engagement: exploring the loyalty nexus", Journal Journal of Marketing Management, Vol. 27 Nos 7-8, pp. 785-807.

31. Hollebeek, L., Glynn, M. and Brodie, R. (2014), "Consumer brand engagement in social media: conceptualization, scale development and validation", Journal of Interactive Marketing, Vol. 28 No. 2, pp. 149-165.

32. Hollebeek, L.D., Srivastava, R.K. and Chen, T. (2019), "SD logic-informed customer engagement: integrative framework, revised fundamental propositions, and application to CRM", Journal of the Academy of Marketing Science, Vol. 47 No. 1, pp. 161-185.

33. Ismail, A.R. (2017), "The influence of perceived social media marketing activities on brand loyalty: the mediation effect of brand and value consciousness", Asia Pacific Journal of Marketing and Logistics, 
BILAL et al., Journal of Business Strategy, Finance and Management, Vol. 02(1 \& 2) 44-55 (2021) 54

Vol. 29 No. 1, pp. 129-144.

34. Jalilvand, M. R., \&Samiei, N. (2012). The impact of electronic word of mouth on a tourism destination choice. Internet Research.

35. Kim, A.J. and Ko, E. (2010), "Impacts of luxury fashion brand's social media marketing on customer relationship and purchase intention", Journal of Global Fashion Marketing, Vol. 1 No. 3, pp. 164-171.

36. Kim, J. and Lee, K.H. (2019), "Influence of integration on interactivity in social media luxury brand communities", Journal of Business Research, Vol. 99, pp. 422-429.

37. Kim, K. H., Ko, E., Xu, B., \& Han, Y. (2012). Increasing customer equity of luxury fashion brands through nurturing consumer attitude. Journal of Business Research, 65(10), 1495-1499.

38. Klein, J. G., Ettenson, R., \& Morris, M. D. (1998). The animosity model of foreign product purchase: An empirical test in the People's Republic of China. Journal of marketing, 62(1), 89-100.

39. Liang, L., Cai, Y., Barratt, B., Lyu, B., Chan, Q., Hansell, A. L., ...\& Tong, Z. (2019). Associations between daily air quality and hospitalisations for acute exacerbation of chronic obstructive pulmonary disease in Beijing, 2013-17: an ecological analysis. The Lancet Planetary Health, 3(6), e270-e279.

40. Lien, C. H., Cao, Y., \& Zhou, X. (2017). Service quality, satisfaction, stickiness, and usage intentions: An exploratory evaluation in the context of WeChat services. Computers in human behavior, 68, 403-410.

41. Lin J and Kloet DJ (2019) Platformization of the unlikely creative class: Kuaishou and Chinese digital cultural production. Social Media + Society. DOI: 10.1177/2056305119883430.

42. Ma, L. and Zhan, M. (2016), "Effects of attributed responsibility and response strategies on organizational reputation: a meta-analysis of situational crisis communication theory research", Journal of Public Relations Research, Vol. 28, pp. 102-119.

43. Malthouse, E. C., Haenlein, M., Skiera, B., Wege, E., \& Zhang, M. (2013). Managing customer relationships in the social media era: Introducing the social CRM house. Journal of interactive marketing, 27(4), 270-280.

44. Martos-Partal, M., Gonzalez-Benito, O. and
Fustinoni-Venturini, M. (2015), "Motivational profiling of store brand shoppers: differences across quality tiers", Marketing Letters, Vol. 26 No. 2, pp. 187-200.

45. Merrilees, B. (2016), "Interactive brand experience pathways to customer-brand engagement and value co-creation", The Journal of Product and Brand Management, Vol. 25 No. 5, pp. 402-408.

46. Mishra, A. (2019), "Antecedents of consumers' engagement with brand-related content on social media", Marketing Intelligence and Planning, Vol. 37 No. 4, pp. 386-400.

47. MSI (2018), 2018 - 2020 Research Priorities, Marketing Science Institute, Boston, MA

48. Nieborg DB and Poell T (2018) Theplatformization of cultural production: theorizing the contingent cultural commodity. New Media \& Society 20(11): 4275-4292.

49. Nunnally, J. C. (1978). An overview of psychological measurement. Clinical diagnosis of mental disorders, 97-146.

50. Pansari, A. and Kumar, V. (2017), "Customer engagement: the construct, antecedents, and consequences", Journal of the Academy of Marketing Science, Vol. 45 No. 3, pp. 294-311.

51. Park, H. and Reber, B.H. (2011), "The organization-public relationship and crisis communication: the effect of the organization-public relationship on publics' perceptions of crisis and attitudes toward the organization", International Journal of Strategic Communication, Vol. 5, pp. 240-260.

52. Plantin J-C, Lagoze C, Edwards PN, et al. (2018) Infrastructure studies meet platform studies in the age of Google and Facebook. New Media \& Society 20(1): 293-310.

53. Rohm, A., Kaltcheva, V.D. and Milne, G.R. (2013), "A mixed-method approach to examining brand consumer interactions driven by social media", Journal of Research in Interactive Marketing, Vol. 7 No. 4, pp. 295-311.

54. Schulze, C., Sch€oler, L. and Skiera, B. (2015), "Customizing social media marketing", MIT Sloan Management Review, Vol. 56 No. 2, pp. 8-10

55. Scott, Elizabeth S., and RobertE. Scott."Marriage as relational contract." Virginia Law Review (1998): 1225-1334.

56. Shao, G. (2009), "Understanding the appeal of user-generated media: a uses and 
BILAL et al., Journal of Business Strategy, Finance and Management, Vol. 02(1 \& 2) 44-55 (2021) 55

gratification perspective", Internet Research, Vol. 19 No. 1, pp. 7-25.

57. Shen, B. and Bissell, K. (2013), "Social media, social me: a content analysis of beauty companies' use of Facebook in marketing and branding", Journal of Promotion Management, Vol. 19 No. 5, pp. 629-651.

58. Simon, F. and Tossan, V. (2018), "Does brandconsumer social sharing matter?A relational framework of customer engagement to brandhosted social media", Journal of Business Research, Vol. 85, pp. 175-184.

59. Statista (2019b), Active Social Network Penetration in Selected Countries as of January 2019, available at:https://www.statista.com/ statistics/282846/regular-social-networkingusage-penetration worldwideby- country (accessed 22 May 2019).

60. Tess, P.A. (2013), "The role of social media in higher education classes (real and virtual)-A literature review", Computers in Human Behaviour, Vol. 29 No. 5, pp. 60-68.

61. Trump, R.K. (2014), "Connected consumers' responses to negative brand actions: the roles of transgression self-relevance and domain", Journal of Business Research, Vol. 67, pp. 1824-1830

62. Wang, X., Yu, C. and Wei, Y. (2012), "Social media peer communication and impacts on purchase intentions: a consumer socialization framework", Journal of Interactive Marketing, Vol. 26 No. 4, pp. 198-208.

63. Webber, A. L. (2017, August 8). World's most influential luxury fashion brands for 2017. Retrieved from CEOworld Magazine: https://ceoworld.biz/2017/08/08/worldsmostinfluential-luxury-fashion-brands-for-2017.

64. Wixom, B. H., \& Watson, H. J. (2001).An empirical investigation of the factors affecting data warehousing success. Management Information Systems Quarterly, 25(1), 17-41. doi:10.2307/3250957.

65. Xu, X., Yang, G., Tan, Y., Liu, J., \& Hu, H. (2018). Ecosystem services trade-offs and determinants in China's Yangtze River Economic Belt from 2000 to 2015. Science of the Total Environment, 634, 1601-1614.

66. Yang, C. H., Yue, J., Pfeffer, S. R., Handorf, C. R., \&Pfeffer, L. M. (2011). MicroRNA miR-21 regulates the metastatic behavior of B16 melanoma cells. Journal of Biological Chemistry, 286(45), 39172-39178.

67. Yang, Y., Asaad, Y. and Dwivedi, Y. (2017), "Examining the impact of gamification on intention of engagement and brand attitude in the marketing context", Computers in Human Behavior, Vol. 73, pp. 459-469.

68. Zeng, B. and Gerritsen, R. (2014), "What do we know about social media in tourism? A review", Tourism Management Perspectives, Vol. 10, pp. 27-36.

69. Zhu, Y.Q. and Chen, H.G. (2015), "Social media and human need satisfaction: implications for social media marketing", Business Horizons, Vol. 58 No. 3, pp. 335-345. 